Canadian Science Publishing

Canadian Journal of Earth Sciences Revue canadienne des sciences de la Terre

\title{
Recovery brachiopod associations from the lower Silurian of South China and their paleoecological implications
}

\begin{tabular}{|r|l|}
\hline Journal: & Canadian Journal of Earth Sciences \\
\hline Manuscript ID & cjes-2015-0193.R1 \\
\hline Manuscript Type: & Article \\
\hline Complete List of Authors: & $\begin{array}{l}\text { HUANG, Bing; Nanjing Institute of Geology and Palaeontology, Chinese } \\
\text { Academy of Sciences, } \\
\text { Zhan, Renbin; Nanjing Institute of Geology and Palaeontology } \\
\text { Wang, Guangxu; Nanjing Institute of Geology and Palaeontology, Chinese } \\
\text { Academy of Sciences }\end{array}$ \\
\hline Keyword: & \begin{tabular}{l} 
Recovery, brachiopod, South China, paleoecology, Network Analysis \\
\hline
\end{tabular} \\
\hline
\end{tabular}

SCHOLARONEm

Manuscripts 
1 Recovery brachiopod associations from the lower Silurian of South China and their

2 paleoecological implications

3

$4 \quad$ HUANG Bing, ZHAN Renbin and WANG Guangxu

5

6 Affiliation and address for all authors: State Key Laboratory of Palaeobiology and

7 Stratigraphy, Nanjing Institute of Geology and Palaeontology, Chinese Academy of

8 Sciences, 39 East Beijing Road, Nanjing 210008, China.

9

10 Corresponding author: Bing HUANG (e-mail: bhuang@nigpas.ac.cn; Tel:

$11+862583282189)$.

12 
Abstract: A recovery brachiopod fauna occurs in the lower Niuchang Formation (upper Rhuddanian-lower Aeronian, Llandovery) of the Xinglongchang section, Meitan County, northern Guizhou Province, South China. Nine collections were made at the section, all of which are dominated by brachiopods, and three associations are recognized here and their paleoecology is discussed. Paleoenvironmental analysis shows a shallowing upward trend for the lower Niuchang Formation although a global transgression was happening at that time. The balance between the global transgression and the regional Qianzhong Uplift guaranteed a stable environment for the formation of the Niuchang Formation and the recovery of brachiopods in South China after the end-Ordovician mass extinction. In addition to the traditional methods of PCA and CA, a relatively new technique to paleontology, "Network Analysis" (NA), is applied successfully in this study. It is suggested that Network Analysis could be used as one of the supporting methods in investigating brachiopod paleoecology.

Keywords: Recovery, brachiopod, South China, paleoecology, Network Analysis.

\section{Introduction}

Following the end-Ordovician mass extinction, the interval of the latest

Ordovician to the earliest Silurian was marked by a widespread transgression (Sheehan 1973, 2001; Brenchley et al. 1994, 2003; Harper and Rong 1995). The earliest Silurian brachiopod fauna has been documented from a number of regions (see Cocks and Rong 2008; Rong and Cocks 2014 for review). However, with rare 
exceptions (e.g. Rong et al. 2013), the precise age of most of those assemblages is not sure. Recently, we reported a Dicoelosia (Brachiopoda) species in the benthic shelly assemblages of the lower Niuchang Formation of South China (Huang et al. 2013).

Constrained by graptolite data, the associated shelly fauna was assigned to the late Rhuddanian (early Llandovery), which belongs to the recovery interval after the end-Ordovician mass extinction.

From the rocks immediately above the Dicoelosia horizon but still in the lower Niuchang Formation (Huang et al. 2013), more collections have been made intensively. Here, we will analyze the taxonomic composition of the brachiopod fauna from the entire section, and conduct a paleoecological analysis, including differentiating brachiopod-dominated associations and discussing their paleoecology. Under the general background of global transgression, the environmental settings of the brachiopod fauna from the Niuchang Formation will be investigated taking the regional tectonic activity into account.

A method relatively new to paleoecological study, Network Analysis (NA), is applied for the first time together with Principal Component Analysis (PCA) and Cluster Analysis (CA). Concerning the advantages and disadvantages of PCA and CA, we suggest that the traditional numerical methods like PCA and CA should be complemented by NA in deriving the most comprehensive paleoecological information. 
The material was collected from the lower Niuchang Formation at Xinglongchang section, $1 \mathrm{~km}$ southeast of Xinglong Village, southeast of Meitan County Town, northern Guizhou, South China (GPS: 27²4'24.6"N, 107³3'02.0"E)

(Fig. 1). Sedimentologically the Niuchang Formation belongs to the nearshore, shallower-water, clastic facies (Rong and Zhan 2004). The rocks of this formation are characterized by brownish-yellow silty mudstone or grey mudstone that includes several fossil groups, such as brachiopods, trilobites, and a few bryozoans and graptolites.

For the age of the brachiopod fauna, the lower part of the section (AGI 521-522) is suggested of the late Rhuddanian age (Huang et al. 2013). AGI 524 is about $1 \mathrm{~m}$ above AGI 522, and there is no lithological change from AGI 522 to AGI 532 (Fig. 2).

Thus, the age of the brachiopods at this entire section may be proposed as late Rhuddanian to the earliest Aeronian, early Silurian.

A preliminary study on the brachiopods (from 9 collections: AGI 521-522, 524-527 and 530-532) indicates the presence of 6 major groups of brachiopods, including orthids, strophomenids, rhynchonellids, atrypids, athyridids, and spiriferids, represented by 14 genera, amongst which Eostropheodonta, Katastrophomena, Levenea, Dicoelosia, Thulatrypa and Eospirifer are abundant, and Aegiria, Leptellina (Merciella), Fardenia, Chrustenopora?, Epitomyonia, Zygospiraella, Eospirigerina and Whitfieldella are less common. Orthids and strophomenids are predominant in both abundance and generic diversity. The fossiliferous beds of the Xinglongchang section can be roughly divided into three parts. The brachiopods of the lower part 
have already been published (Huang et al. 2013), and the representative species occurring in the upper part of the section are shown in Figure 3.

After identifying specimens bed by bed, we compile a range chart for the brachiopod genera from the lower Niuchang Formation (Fig. 2). From the diagram, a trend of diversity decrease and a variation of brachiopod composition can be recognized. Here, we will analyze the binary data of taxonomic composition (see Table A1) for the nine collections.

\section{Methods}

To investigate the paleoecology of the brachiopods from the lower Niuchang Formation at the Xinglongchang section, differentiating brachiopod-dominated associations is a key step. Traditionally, statistical methods, such as PCA and CA are used (e.g. Rong and Zhan 2006) to recognize associations or even communities, and which will also be adopted in our study using the software PAST (version 3.01, Hammer et al. 2001). However, information obtained from these methods has some limitation.

A new method, called "Network Analysis" (NA), can provide a network diagram, by which more information about the structure of the dataset is shown. The study of network systems has a long history, but it has experienced a particular surge of interest in the past decade (Newman 2006), mainly due to the fact that many systems of scientific interest can be represented as networks - sets of nodes or vertices joined in pairs by lines or edges. Recently, NA has often been used in biogeographic studies 
101

102

(e.g. Sidor et al. 2013). For biogeographic studies, NA can provide detailed insight into the underlying structure of the biogeographic assemblages, and the network diagrams visualize the similarities and differences between faunas at various localities (Vilhena and Antonelli 2015). Similarly, the network diagram can visualize the connection between different collections within a certain area (or region), through which some unique associations or even communities could be differentiated. Here, for the first time, we apply this method to paleoecological study, in order to visualize the relationships among different brachiopod associations. Instead of species-locality data used in biogeographic studies, a genus-collection dataset is produced for this study. The connectivity between two collection nodes is established through the taxa they share, which are inherently a bipartite network. Therefore the bipartite network method incorporates both collection data and the presence-absence information of different taxa, and aims to minimize information loss.

The advantages of using NA compared to such traditional methods as PCA and CA can be summarized as: 1) PCA and CA cannot detect the relationship between two collections which apparently do not share common taxa. Compared with direct connection between two data columns always measured by the similarity index (e.g. CA), NA can use the data of collection-taxon, and takes into account the indirect connections between collections (see Vilhena and Antonelli 2015, fig. 1 for detail). 2) It is difficult to investigate the connection between collection and taxa via the results from CA or PCA, whereas the network diagram from NA can show how a collection links to others via their common taxa. 3) Last but not least, the network method also 
123

124

calculates the connectivity, clustering and range size of data, and detects the community structure of the fauna investigated (Fortunato 2010). Through various functions NA could provide, more information from the data can be revealed by NA than the traditional methods. The advantages of this new method will be shown in the results of the study. However, the disadvantages of this method are also apparent, such as the connectivity between two indirectly linked nodes should be treated as an underlying relation rather than a real connection. Without other information, misinterpretation of the connections between different collections could cause an imprecise or even incorrect conclusion.

There are several free software for performing network analysis. Gephi (v0.8.2; www.gephi.org) is used in this study to visualize the bipartite genus-collection networks. The following visualization settings were used: Force Atlas 2, number of threads 2 , edge weight influence 1.0 , scaling 10.0 , gravity 1.0 , tolerance 0.1 , and approximation 1.2. Average Degree of the network was calculated and out degree was used to detect the size and gray scale of the collection nodes.

\section{Brachiopod associations and their environmental settings}

Based on binary data of the collections (see Appendix), PCA was performed firstly and three brachiopod-dominated associations were recognized (Fig. 4A). In order to investigate the relationship between collections in detail, we conducted CA (cluster analysis) using four similarity indices: Jaccard, Dice, Ochiai and Raup-Crick.

Considering the consistency of the results derived from these indices, the dendrogram 
145 from Raup-Crick is shown here (Fig. 4B). By the bipartite network analysis, the

146 diagram generated by the software Gephi (Fig. 5) supports the results from PCA and 147 CA.

148 Some phenomena from the bipartite network diagram could be observed. 1)

149 Three associations can be recognized, which are similar to the results of PCA and CA.

150 2) The taxonomic information of each collection is shown. 3) The connection among

151 collections based on their common taxa is displayed. 4) The diversity of each

152 collection is visualized by the size and gray scale of the collection nodes through the

153 "out degree", which is represented by the number of edges of each node. Almost all

154 information the study needs from the binary data (Appendix) could be visualized by

155 the NA.

156 From the three methods above, three associations based mainly on faunal

157 composition were clearly recognized: the Dicoelosia-Zygospiraella association, the

158 Eostropheodonta-Levenea association and the Thulatrypa-Eospirifer association,

159 which are described as follows:

160

1) The Dicoelosia-Zygospiraella association (AGI 521-522)

161

This association is represented by two collections with 196 specimens at AGI 521

162 and AGI 522. Ten genera occur in this association, representing the highest diversity

163 in the section. Dicoelosia cathaysiensis accounts for $41.8 \%$ of the total and

165 include abundant crinoids, a few bryozoans, trilobites, and rare graptolites.

166 The population of Dicoelosia cathaysiensis was assigned to a BA3 environment

167 with several lines of evidences (Huang et al. 2013). After careful consideration for the 
168 Dicoelosia-Zygospiraella association, especially some deep water indicators, such as 169 Epitomyonia, Aegiria, the bathymetry of the collections AGI 521-522 can now be 170 refined to lower BA3 to BA4.

171 2) The Eostropheodonta-Levenea association (AGI 524-527, AGI 530)

172 This association includes 5 samples with only 59 specimens in total, mainly due 173 to its low brachiopod diversity leading to a relatively small collection made in the 174 field respectively. However, rarefaction analysis for these collections shows that the 175 sampling is sufficient. Faunal composition of this association is quite different from 176 the older Dicoelosia-Zygospiraella association. Eostropheodonta (50.8\%) is the most 177 common genus followed by Levenea (33.9\%). Graptolites are not found in this 178 association, but other kinds of shelly fossils, such as trilobites, crinoids and bryozoans are present.

This association is thought to have lived in a shallower environment owing to several lines of evidences. The sharply decreased brachiopod generic diversity (from 10 to 5) could be one of the clues. The lithology in which the brachiopods occur also suggests shallow water habitats, and a turbulent environment evidenced by the disarticulation of the brachiopod valves. Deeper water indicators, such as Dicoelosia and Epitomyonia, disappeared from the collection AGI 524, indicating a shallow environment corresponding to upper BA3 to BA2 for the Eostropheodonta-Levenea association.

3) The Thulatrypa-Eospirifer association (AGI 531-532)

The Thulatrypa-Eospirifer association is the most interesting one among all collections. Thulatrypa is a newly erected genus (Huang et al. 2016), and several 
191 similar and contemporary assemblages are found in other areas of South China. The

192 diversity of the association further decreases compared with its underlying

193 associations, and only 4 brachiopod genera are identified within 151 specimens. The

194 major components of the associations are totally different from the other two

195 associations. Thulatrypa (68.2\%) becomes the most abundant genus with proportion

196 significantly higher than the others, and Eospirifer (18.5\%) takes the second position.

197 Compared with the associations preceding it, i.e. the Eostropheodonta-Levenea

198 association and the Dicoelosia-Zygospiraella association, the Thulatrypa-Eospirifer

199 association is closer to the Eostropheodonta-Levenea association, mainly according

200 to their low diversity, similar lithology, and absence of deeper water indicators, which

201 suggest a similar shallow water environment for the Thulatrypa-Eospirifer

202 association.

203

204

\section{Paleoecological implications}

From the basal to the upper part of the Xinglongchang section, a shallowing upward trend is indicated. The brachiopod associations recognized in this paper are of late Rhuddanian to the earliest Aeronian age when a global transgression was occurring. The shallowing upward trend indicated by these associations in South China apparently conflicted with the global trend. Our study area was paleogeographically located in the northern marginal belt of the Qianzhong (central Guizhou) Old Land, southern Upper Yangtze Region. Although the beginning of the

212 Silurian was marked by a significant and rapid eustatic sea level rise, the Qianzhong 
regional tectonic movement corresponding to the Caledonian orogeny in Europe and the Taconic orogeny in North America (e.g. Rong et al. 2011). The global sea level drop caused by the Late Ordovician glaciation together with the Qianzhong Uplift near the end of Ordovician truncated the youngest Ordovician rocks in northern Guizhou, South China. Consequently, a near shore shelly fauna inhabited this area in the southern marginal area of the Upper Yangtze epicontinental sea during the early Llandovery transgression. Xinglongchang was located very close to the paleoshoreline, indicating a relatively shallow water environment.

The balance between the global transgression and the Qianzhong Uplift guaranteed a stable regional environment for the development of the brachiopod-dominated associations. The Qianzhong Uplift might play a more important role during the recovery interval after the end-Ordovician mass extinction, causing a shallowing upward trend recorded at this section. This provided a shallow water benthic regime that favored the recovery of brachiopods in South China.

\section{Conclusion}

The beginning of the Silurian was marked by a significant and rapid eustatic sea level rise, which induced an anoxic event in many regions of the world; however, shelly biotas of this interval have been discovered in a number of regions. In this study, we report a recovery brachiopod fauna from the lower Niuchang Formation (upper Rhuddanian-lower Aeronian, Llandovery) at the Xinglongchang section, Meitan County, northern Guizhou Province, South China. Nine collections with mainly brachiopod fossils are analyzed using different numerical methods, and three brachiopod-dominated associations are recognized. On the basis of paleoecological 
analyses for these associations, a shallowing upward trend was deduced for the study area and the southern part of South China. Under the background of eustatic transgression, such environmental setting might be related with the regional tectonic activity, i.e. the Kwangsian orogeny. In particular, the Qianzhong Uplift was progressing during Rhuddanian to early Aeronian, which guaranteed a shallow water "refugium" in the study area after the biotic crisis.

In addition to the traditional numerical methods like PCA and CA, a method relatively new to paleoecology study, "Network Analysis" (NA) is applied in this paper. This method can reveal more detailed information than those traditional methods about the relationship between different collections. But, since some information revealed by NA could be misleading, the results of this method should be used cautiously as one of the supporting evidences in our paleoecological investigation.

\section{Acknowledgements}

The authors would like to express their sincere thanks to Zhou Zhiqiang (Xi'an Institute of Geology and Mineral Resources) for his kind help in the field; Rong Jiayu (NIGP, Chinese Academy of Sciences) and Jin Jisuo (Western University, Ontario) for their valuable suggestions on the academic part of this paper. The comments and suggestions from Ian Percival (Geological Survey of New South Wales), an anonymous reviewer and the journal editors substantially improved the clarity of the manuscript. Financial supports for this study are from the National Natural Science Foundation of China (NSFC) NO. 41472006, 41221001, 41530103, and the State Key 
261 Laboratory of Palaeobiology and Stratigraphy. This paper is also a contribution to

262 IGCP Project 591 "Early to Middle Paleozoic Revolution".

263

264

265

266

267

268

269

270

271

272

273

274

275

\section{References}

Brenchley, P.J., Carden, G.A., Hints, L., Kaljo, D., Marshall, J.D., Martma, T., Meidla, T., and Nolvak, J. 2003. High-resolution stable isotope stratigraphy of Upper Ordovician sequences: Constraints on the timing of bio events and environmental changes associated with mass extinction and glaciation. Geological Society of America Bulletin, 115: 89-104.

Brenchley, P.J., Marshall, J.D., Carden, G.A.F., Robertson, D.B.R., Long, D.G.F., Meidla, T., Hints, L., and Anderson, T. 1994. Bathymetric and isotopic evidence for a short-lived Late Ordovician glaciation in a greenhouse period. Geology, 22: 295-298.

Cocks, L.R.M., and Rong, J.Y. 2008. Earliest Silurian faunal survival and recovery after the end Ordovician glaciation: evidence from the brachiopods. Earth and Environmental Science Transactions of the Royal Society of Edinburgh, 98: 291-301.

Fortunato, S. 2010. Community detection in graphs. Physics Reports, 486(3-5): 75-174.

Hammer, Ø., Harper, D.A.T., and Ryan, P.D. 2001. PAST: Palaeontological Statistics software package for education and data analysis. Palaeontologia Electronica, 4: $9 \mathrm{pp}, 178 \mathrm{~kb}$. 
283

284

285

286

287

Harper, D.A.T., and Rong, J.Y. 1995. Patterns of change in the brachiopod faunas through the Ordovician-Silurian interface. Modern Geology, 20: 83-100.

Huang, B., Rong, J.Y., and Harper, D.A.T. 2013. A new survivor species of Dicoelosia (Brachiopoda) from Rhuddanian (Silurian) shallower-water biofacies in South China. Journal of Paleontology, 87(2): 232-242.

Huang, B., Baarli, B.G., Zhan, R.B. and Rong, J.Y. 2016. A new early Silurian brachiopod genus, Thulatrypa, from Norway and South China, and its palaeobiogeographical significance. Alcheringa, 40: Published online. Available from: http://www.tandfonline.com/doi/full/10.1080/03115518.2016.1092066.

Newman, M.E.J. 2006. Modularity and community structure in networks. Proceedings of the National Academy of Sciences, 103(23): 8577-8582.

Rong, J.Y., and Cocks, L.R.M. 2014. Global diversity and endemism in Early Silurian (Aeronian) brachiopods. Lethaia, 47: 77-106.

Rong, J.Y., Chen, X., Wang, Y., Zhan, R.B., Liu, J.B., Huang, B., Tang, P., Wu, R.C., and Wang, G.X. 2011. Northward expansion of central Guizhou Oldland through the Ordovician and Silurian transition: Evidence and implications. Scientia Sinica Terrae, 41: 1407-1415.

Rong, J.Y., Huang, B., Zhan, R.B., and Harper, D.A.T. 2013. Latest Ordovician and earliest Silurian brachiopods succeeding the Hirnantia fauna in south-east China. Special Papers in Palaeontology, 90: 1-142.

Rong, J.Y., Xu, H.K., and Yang, X.C. 1974. Silurian brachiopods. In The Handbook of Stratigraphy and Paleontology in Southwest China. Edited by Nanjing 

Institute of Geology and Palaeontology. Science Press, Beijing. pp. 195-208. [In Chinese.]

Rong, J.Y., and Zhan, R.B. 2004. Niuchang Formation, a new lithostratigraphic unit of Llandovery (Silurian) from the Upper Yangtze Region. Journal of Stratigraphy, 28(4): 300-306. [In Chinese.]

Rong, J.Y., and Zhan, R.B. 2006. Surviving the end-Ordovician extinctions: evidence from the earliest Silurian brachiopods of northeastern Jiangxi and western Zhejiang provinces, East China. Lethaia, 39: 39-48.

Sheehan, P.M. 1973. The relation of late Ordovician glaciation to the Ordovician-Silurian changeover in North American brachiopod faunas. Lethaia, 6: $147-154$.

Sheehan, P.M. 2001. The Late Ordovician mass extinction. Annual Review of Earth and Planetary Sciences, 29: 331-364.

Sidor, C.A., Vilhena, D.A., Angielczyk, K.D., Huttenlocker, A.K., Nesbitt, S.J., Peecook, B.R., Steyer, J.S., Smith, R.M.H., and Tsuji, L.A. 2013. Provincialization of terrestrial faunas following the end-Permian mass extinction. Proceedings of the National Academy of Sciences, 110(20): 8129-8133.

Vilhena, D.A., and Antonelli, A. 2015. A network approach for identifying and delimiting biogeographical regions. Nature Communication, 6: 6848. doi: $10.1038 /$ ncomms 7848 . 
327

328

329

330

331

332

333

334

335

336

337

338

339

340

341

342

343

344

345

346

347

348

\section{Figure captions:}

Fig. 1. Location map of Xinglongchang section, Meitan County, northern Guizhou, South China, where occurs the brachiopod associations of the recovery interval after the end-Ordovician mass extinction (modified from Huang et al. 2013).

Fig. 2. Nine collections made in the lower Niuchang Formation (upper Rhuddanian to lowermost Aeronian, Llandovery, lower Silurian) at Xinglongchang section. Range chart showing brachiopod generic composition from AGI 521 to AGI 532.

Fig. 3. Representative brachiopods from AGI 532 except 1, 7 from AGI 530 and 6 from AGI 527. 1-3, 5. Levenea qianbeiensis (Rong et al. 1974), ventral (1,3) and dorsal $(2,5)$ internal moulds, NIGP 163255-163258. 4, 8, 13. Thulatrypa orientalis (Rong et al. 1974), ventral $(4,8)$ and dorsal (13) internal moulds, NIGP 163259-163261. 6, 7. Eostropheodonta sp., ventral (6) and dorsal (7) internal moulds, NIGP 163262-163263. 9-12. Eospirifer sp., ventral internal moulds (9, 10), dorsal internal mould (11) with its external mould (12), NIGP 163264-163266.

Fig. 4. The results of Principal Component Analysis (PCA) (A) and Cluster Analysis (CA) (B) for the 9 collections made from the lower Niuchang Formation at Xinglongchang section. Three brachiopod-dominated associations were consistently recognized, with relative water depths proposed shown in the dendrogram (B). 
349 Fig. 5. The bipartite network diagram of NA supports the results of PCA and CA. 


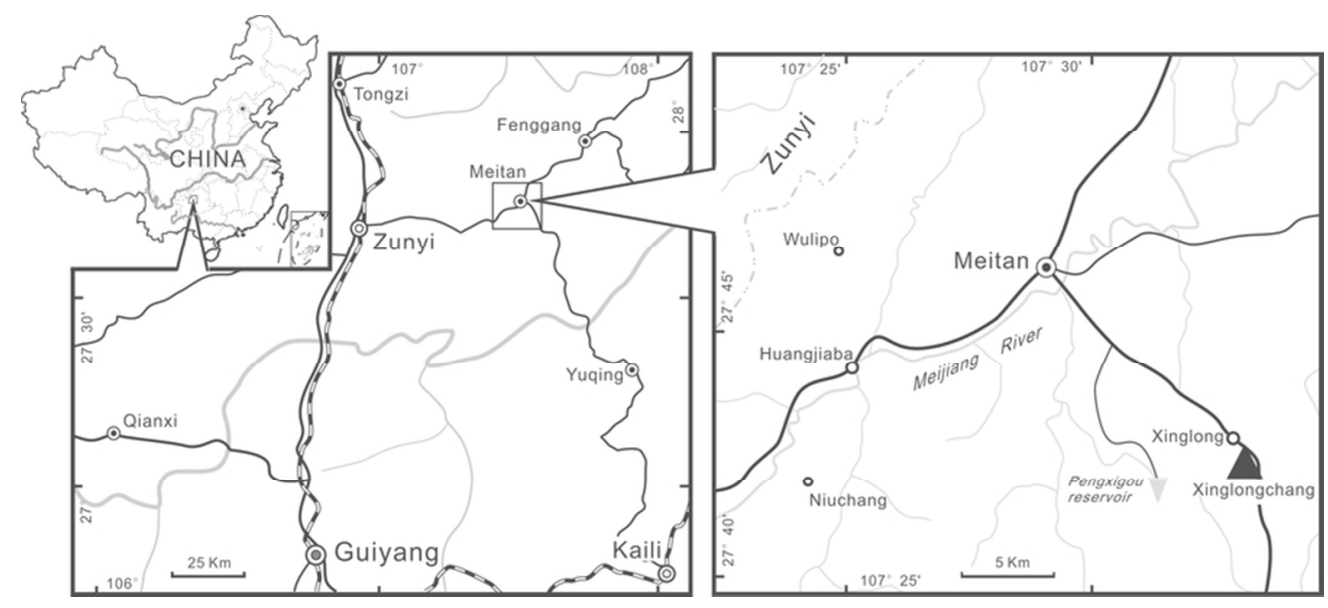

Fig. 1. Location map of Xinglongchang section, Meitan County, northern Guizhou, South China, where occurs the brachiopod associations of the recovery interval after the end-Ordovician mass extinction (modified from Huang et al. 2013).

$76 \times 34 \mathrm{~mm}(300 \times 300 \mathrm{DPI})$ 


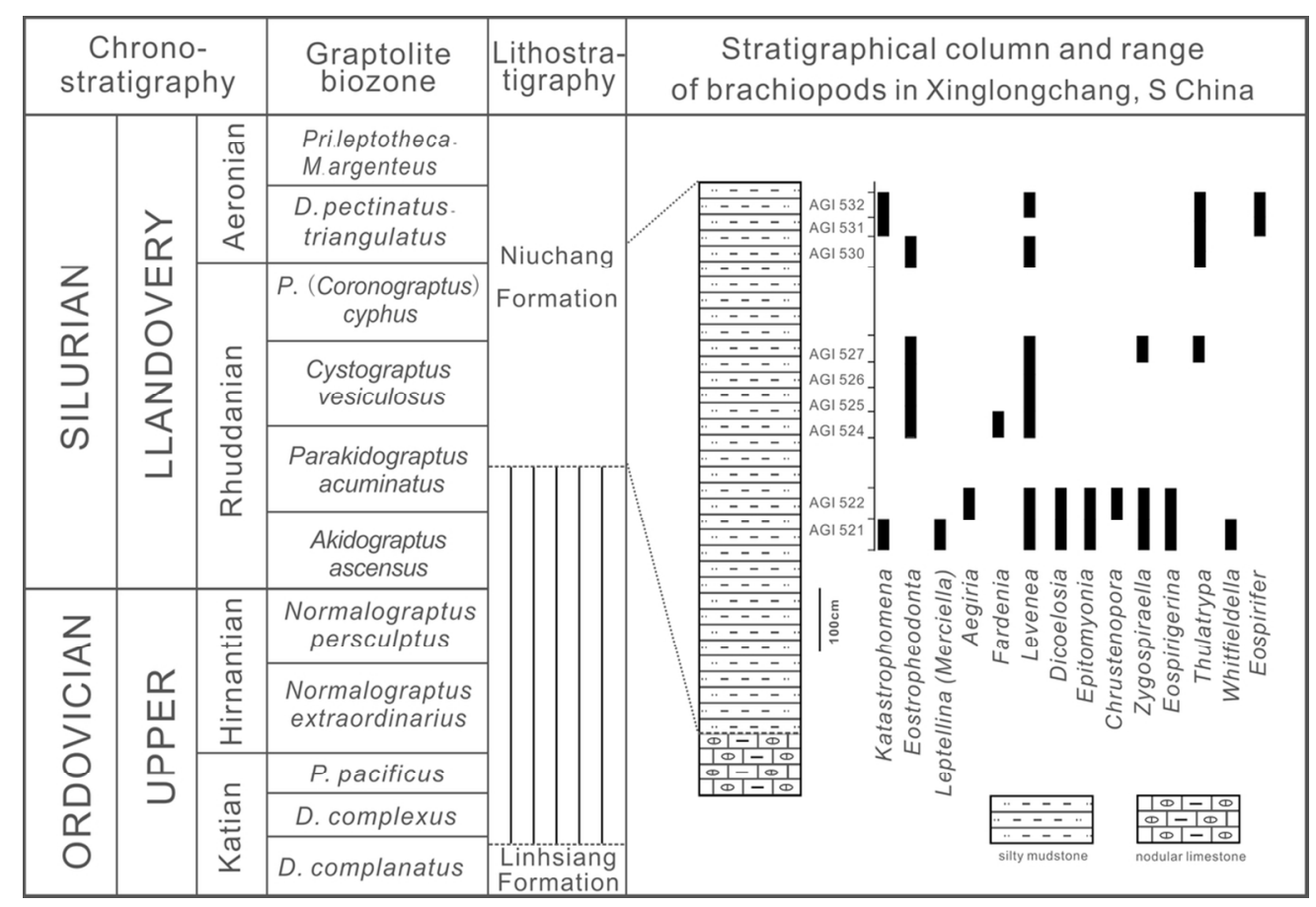

Fig. 2. Nine collections made in the lower Niuchang Formation (upper Rhuddanian to lowermost Aeronian, Llandovery, lower Silurian) at Xinglongchang section. Range chart showing brachiopod generic composition from AGI 521 to AGI 532. $103 \times 70 \mathrm{~mm}(300 \times 300 \mathrm{DPI})$ 

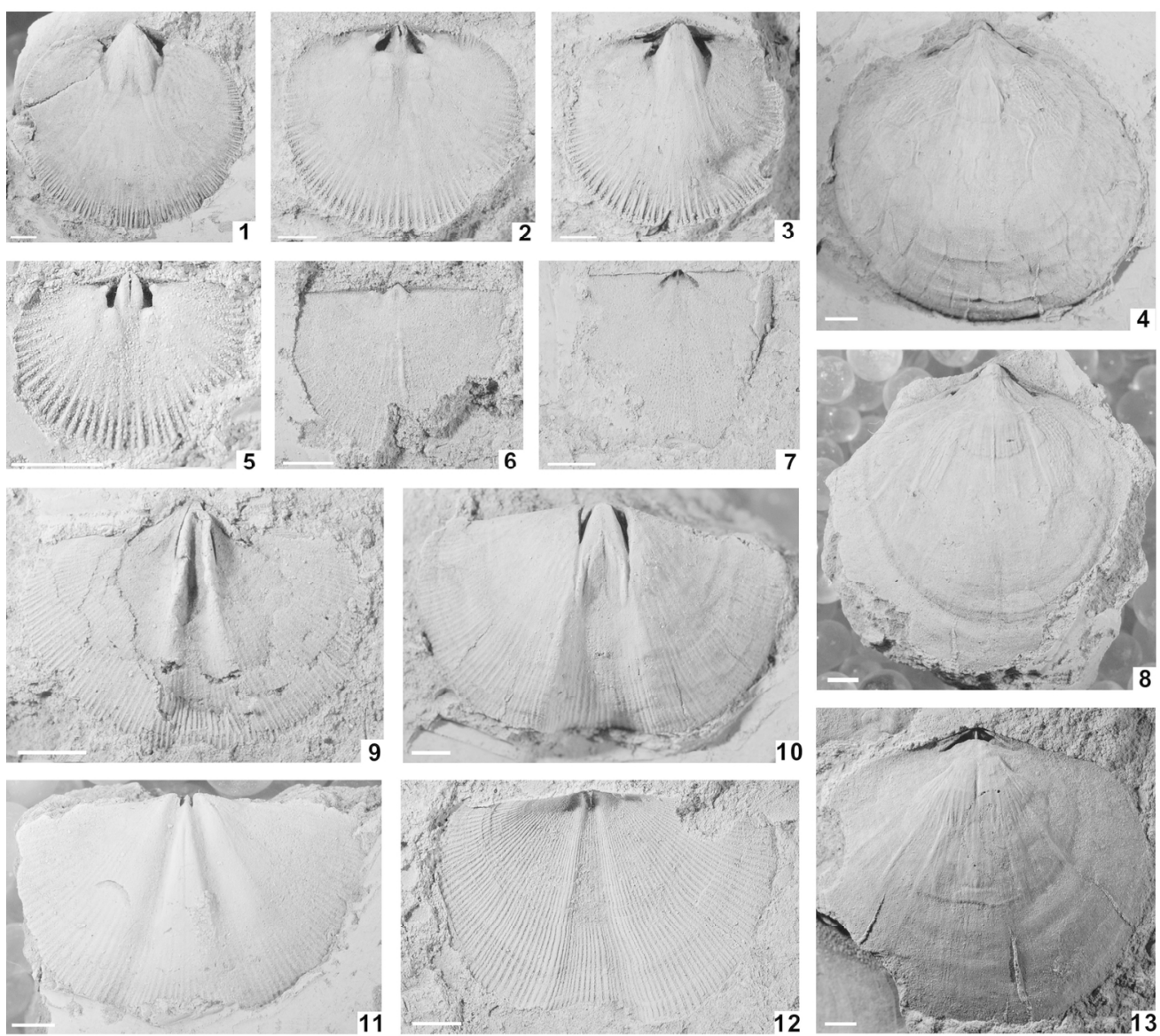

Fig. 3. Representative brachiopods from AGI 532 except 1, 7 from AGI 530 and 6 from AGI 527. \n1-3, 5. Levenea qianbeiensis (Rong et al., 1974), ventral $(1,3)$ and dorsal $(2,5)$ internal moulds, NIGP 163255163258. 4, 8, 13. Thulatrypa orientalis (Rong et al., 1974), ventral (4, 8) and dorsal (13) internal moulds, NIGP 163259-163261. 6, 7. Eostropheodonta sp., ventral (6) and dorsal (7) internal moulds, NIGP $163262-$ 163263. 9-12. Eospirifer sp., ventral internal moulds $(9,10)$, dorsal internal mould (11) with its external mould (12), NIGP 163264-163266. $152 \times 136 \mathrm{~mm}(300 \times 300 \mathrm{DPI})$ 


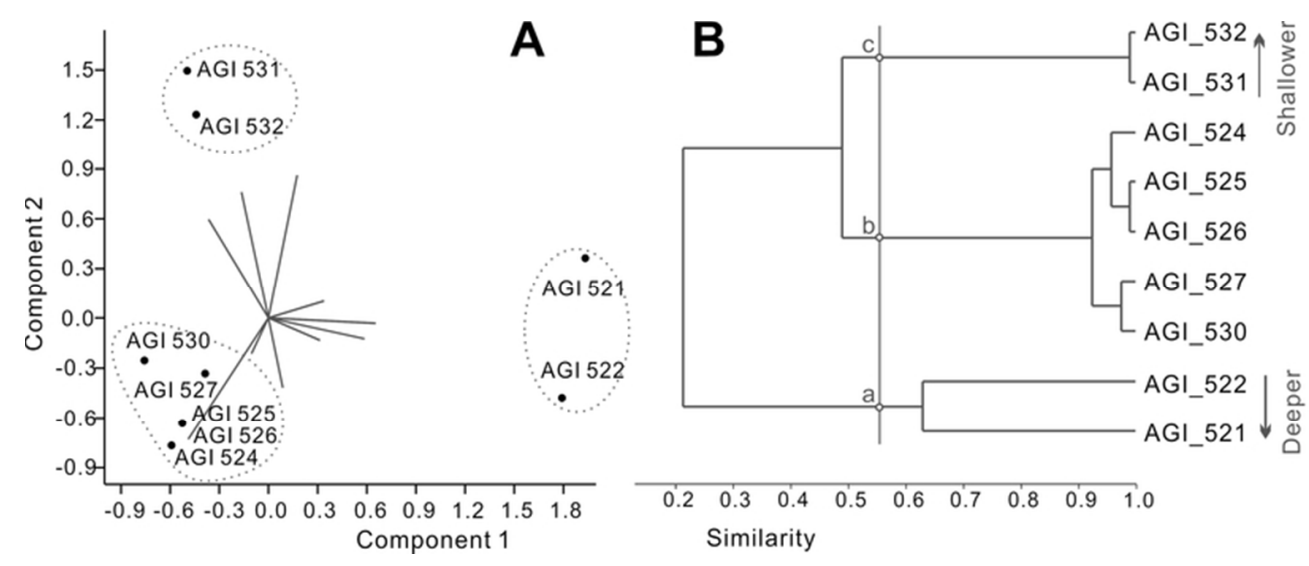

Fig. 4. The results of Principal Component Analysis (PCA) (A) and Cluster Analysis (CA) (B) for the 9 collections made from the lower Niuchang Formation at Xinglongchang section. Three brachiopod-dominated associations were consistently recognized, with relative water depths proposed shown in the dendrogram

(B).

$69 \times 28 \mathrm{~mm}(300 \times 300$ DPI $)$ 


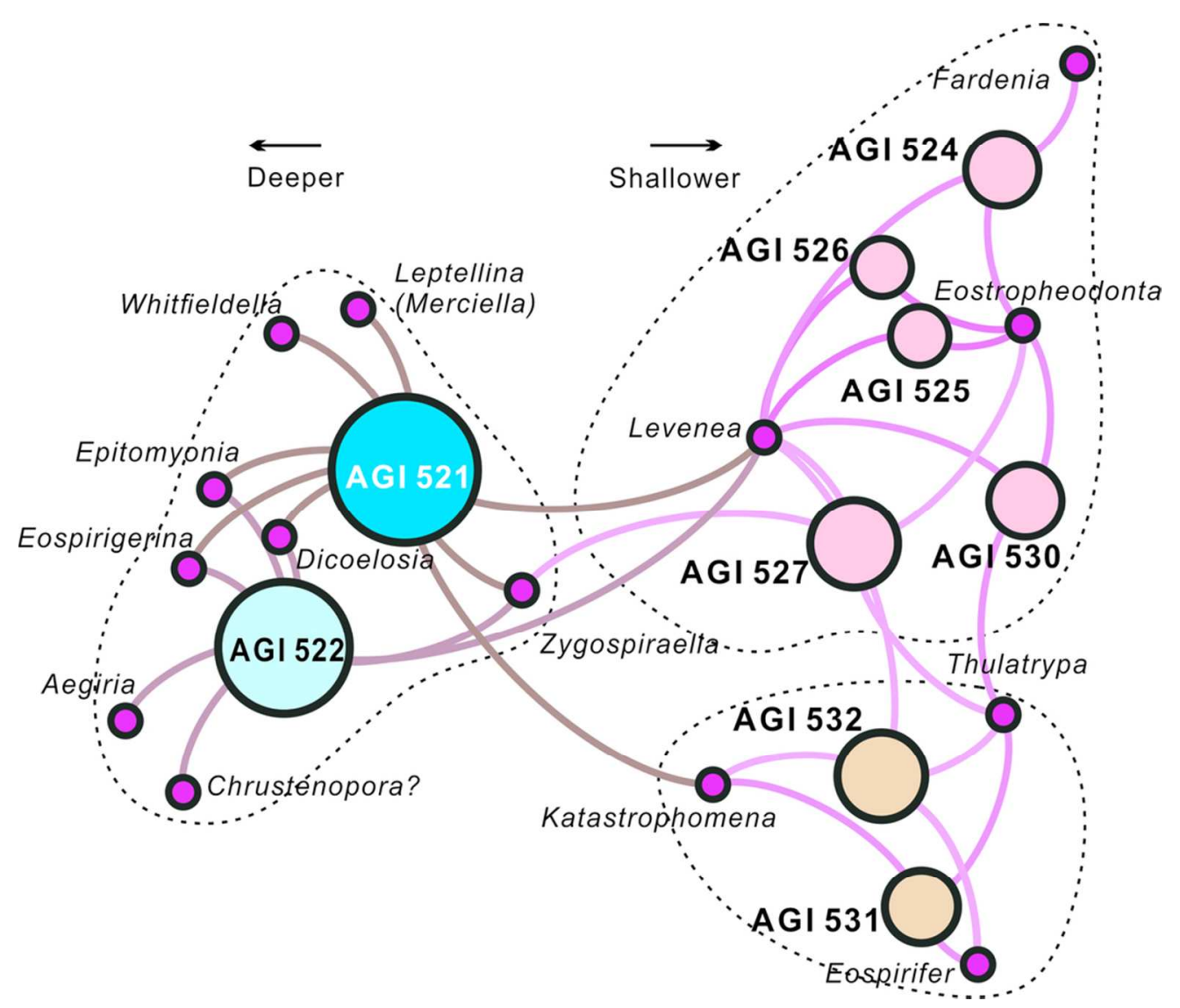

Fig. 5. The bipartite network diagram of NA supports the results of PCA and CA. $89 \times 76 \mathrm{~mm}(300 \times 300$ DPI $)$ 